\title{
THE INTERNATIONAL ROMANI MOVEMENT: NEW VISIONS AND STRATEGIC POSITIONS
}

\author{
N. Georgieva-Stankova*
}

\author{
Regional Development Department, Economics Faculty, Trakia University, Stara Zagora, Bulgaria
}

\begin{abstract}
The paper aims to present key issues in the International Romani Movement (IRM), related to the instrumentalization of ethnic identity and politicization of ethnogenesis. The main argument is that the idea of the transnational non-territorial Roma nation combines traditional and novel aspects in nationbuilding. Ethnic identity, according to the interactionist and circumstantialist approach of Frederik Barth (1969), is a form of social organization, produced in the process of ascription and self-ascription, defined by the ethnic boundary, not the cultural enclosure. Accepting identity as dynamic and relational, we need to consider the process of interaction of the Romani movement with macrosocial political agendas (local, regional, national levels), as well as with the supranational (e.g. EU) level, and the influence of such interaction on the distribution of material and symbolic resources and ethnic representation. The strategic choice of positions of Romani activists and intellectuals is crucial for the future development of the movement. The paper concludes that a hybrid, in-between integrationist position is more viable than isolationism, victimhood and ethnic segregation.
\end{abstract}

Key words: Roma, nation building, ethnic identity construction, politicization of ethnogenesis, Romani intellectuals, hybridity

\section{INTRODUCTION}

New developments in the International Romani Movement (IRM) have engaged the attention of scholars since the collapse of the Communist bloc. With its innovative approach to nationhood, the IRM has been working towards uniting approximately 12 million people under the umbrella term "Roma" in a pan-European Roma nation. Current developments in Romani nation-building can be viewed as the instrumental application of certain political, cultural and symbolic tools with the purpose of rehabilitating a stigmatized identity and building a more respectable image of the Roma. The politicization of Romani ethnogenesis, as defined by Nicolae Gheorghe, one of the leading figures in the IRM, can be understood as the process, in which "a social group, previously occupying a despised and inferior position, [is] moving from this position to some kind of respectability with a sort of equality with other social groups in the

\footnotetext{
*Correspondence to: Nadezhda G. GeorgievaStankova, Regional Development Department, Economics Faculty, Trakia University, Stara Zagora, Mailing address: Student Campus, 6000, Stara Zagora, Economics Faculty, Trakia University, Tel. (+359) 042699211413 ,

E-mail: nadya.georgieva.stankova@gmail.com
}

hierarchy of social stratification on the basis of a revised perception of their identity" (1: 158). Some of the strategies for constructing the Romani nation involve the creation of a formal historical narrative, the formalization of cultural codes and diacritics, the invention of symbols and traditions and the standardization of Romani culture and language. Contrary to such traditional strategies in nation-building, the Roma nationalist case presents a novel perspective on nationhood, as non-territorial and transnational, hence directly implying the possibility that the Roma nation may create a precedent for the eventual demise of the nation-state (Gheorghe cited in 2: 108). This cosmopolitan perspective requires the study of parallel nation-building processes among the Romanies on three different levels: the subnational (local), the national and supranational (transnational) and interaction with existing actors, institutions and political agendas within the wider EU framework.

The aim of the paper is to present key issues in the development of the International Romani Movement, related to the instrumentalization of ethnic identity and politicization of ethnogenesis. The main research objectives are as follows: 1) studying the nature, function and strategies in constructing the new image of the 
Roma, involving processes of interaction with significant bodies and institutions; 2) the influence of this interaction on the distribution of material and symbolic resources as well as on ethnic representation; 3) new trajectories in the IRM vis-à-vis relations with non-Roma partners and institutions; 4) the role and strategic positioning of Roma activists and intellectuals in nation-building processes.

The research methodology comprises several data-collection tools and techniques: documentary analysis of political discourse and policy statements, field work, in-depth interviews with Roma cultural and political activists, project work for OSCE /ODIHR/CPRSI, Warsaw, Poland, as well as attending numerous Roma-related events, conferences, congresses and forums.

The main argument is that the idea of the transnational non-territorial Roma nation combines traditional and novel strategies in nation-building, which are dynamically shaped by processes of interaction, as a response to changes in the macrosocial context and dominant political agendas, as well as by attempts to create national representative bodies and institutions at EU level.

\section{THEORETICAL PREMISES: ETHNIC IDENTITY AND NATION BUILDING}

There are two basic models in identity formation (Stuart Hall cited in 3: 89): an essentialist and a non-essentialist one. The former can be defined by the presence of some "intrinsic essential content" pertinent to any identity, in which a common origin or a common "structure of experience" plays an important role, characterized by the search for the "authentic" or "original" content of identity (ibid.). The latter, non-essentialist model, denies the possibility of existence of separate distinct and stable identities. Therefore, identities are perceived as multiple, rather than singular, always relational and incomplete, processual and dynamic (ibid.). Similarly, theories of nationalism refer to the primordialist vs. social constructivist dichotomy. Culture, for the primordialists, is an essential given and ethnic identities are seen as consisting of some shared cultural traits, "primordial attachments," based on kinship, locality, language, religion and culture (4: 45), which are viewed as natural, stable and immutable (Brass cited in 5: 83). Primordialist theory meets a lot of criticism by contemporary authors. Its main problems are that it tends to romanticize and generalizes identity, treats primordial attachments as coercive, undermines social and historical contextualization and fails to acknowledge that both "nation" and "ethnic group" are predetermined by historical and cultural factors (Sian Jones cited in 6: 193). Nevertheless, primordial attachments may hold strong appeal in processes of politicization of ethnic identity, as they bring a sense of stability, certainty and durability, hence the promise of unity, homogenization and strong organizational capacity.

The non-essentialist model criticizes primordialist certainties. Frederik Barth, the central proponent of circumstantialism, describes ethnicity as the "social organization of cultural difference" (7:15). For him, ethnic identity can be subject to change and transformation in the process of interaction. His key argument is that the boundaries define the groups rather than the "cultural stuff" enclosed by it (ibid.). Ethnic groups are produced by processes of self-ascription, as well as by ascription on the part of external others and social institutions (8: 1). One is capable of shifting their ethnic identifications in accordance with particular circumstances and in pursuit of political goals and selfinterest. Barth's contribution lies in the shift from a static to an interactionist model and in the distinction between ethnicity and culture (8: 2). Ethnic groups are treated not as primordial, but as interest groups, which result from processes of social interaction (6:194).

Glazer and Moynihan (9) represent the second instrumentalist approach to ethnicity. For them, religion, language and cultural differences "become effective foci for group mobilization for concrete political ends," which contest the primacy for such mobilization of both class and nation $(9: 18)$. Ethnicity has certain advantage over social class as a means of collective organization, since being member of a discriminated ethnic group appears to be "more interesting" and prestigious than of a lower socio-economic category (10:14). It is horizontal, therefore more preferable than the vertical and overridden by negative connotations concept of social class, creating "equivalences rather than hierarchies" (ibid.). Ethnic movements become "pressure groups with a noble face" (ibid.), mobilizing certain cultural and purely ethnic diacritics in order to gain political advantage in the struggle for equal recognition. Ethnicity does not serve strictly instrumental purposes. For Daniel Bell, "[e]thnicity has become more salient [than class], because it can combine an interest with an affective tie" (11:169). It turns into a "strategic site" and a "choice," preferred by disadvantaged groups, 
seeking political redress in society in novel ways, aiming to upgrade their status and gain certain privileges (ibid.). In other words, "[t]he upsurge of ethnicity is a cultural gain in that it allows individuals whose identities have been submerged, or whose status has been denigrated, to assert a sense of pride in what they regard as their own. [...]. [T] o claim a set of rights and privileges, which the existing power structures have denied them" (11:174).

Benhabib (12) identifies the positions from which both essentialist and non-essentialist discourses are typically enunciated. The constructivist perspective is that of the observer, of the outsider or of the sociological subject (12: 301), one who is able to deconstruct and analyze thoroughly all the complexities of the contemporary world and take into consideration the interaction of different discourses. The essentialist perspective, on the other hand, presents the search for a stable point of identification in political mobilization; therefore, this is the position most suitable for the group participant (ibid.). A widening hiatus exists between the positions of "sociological enlightenment and social militancy," since while the former may insist on the fluidity and dynamism of identity, the latter militates against any attempt at contesting its stability and integrity (ibid.).

For the needs of the present work, the reconfiguration of Romani identity will be defined as the selection of voluntary identity, an inherent part of ethnic emancipation and the politicization of ethnogenesis, constructed in the process of interaction with significant Others, which is constantly redefining its boundaries according to contextual changes, serving the instrumental purposes of upgrading a stigmatized status in the struggle for recognition and distribution of social resources.

\section{THE POLITICIZATION OF ETHNOGENESIS: THE IRM AND THE ROMA NATION}

The First Roma World Congress was organized in London in in 1971 with one main purpose: to set the basis for uniting the Roma from all over the world and establish symbolically the link with their ancient motherland, India ${ }^{1}$. An agreement was made to

\footnotetext{
${ }^{1}$ The roots of the Romani movement lie in the late $19^{\text {th }}$ - early $20^{\text {th }}$ century, beginning with the struggle of different organizations to achieve better citizenship rights for the Roma, including some attempts at global unification. There is also a brief history of pursuing the dream of Romanestan, related to the Polish Kwiek Roma dynasty, which
}

lobby for the status of nationality for Roma by sending a delegation to the UN. There have been eight World Roma Congresses up to date, organized by the International Romani Union (IRU), striving to become a political representation for all Roma worldwide, develop the cultural traditions, customs and language of the Roma, and contribute to sustaining world piece, liberty and human rights. Parallel to IRU, the Romani National Congress (RNC) developed distinct political demands and ideology. Contrary to the Romani movement in Western Europe, the German civil rights movement did not evolve out of intellectual interest, but was a typical grassroots movement, dealing with key individual and collective issues, regarding elementary freedoms of movement, security, justice and material welfare (13:53). The activities of IRU on language and cultural standardization were met with distrust by the $\mathrm{RNC}$, as for them, the most important issues remain civil rights and those of Roma migrants, refugees and asylum seekers.

Contemporary developments in Romani nationalism are related to the rise of strong anti-Roma sentiments in recent years and the growth of numerous Romani organizations, NGOs and associations, as a response to widespread intolerance and racism. The Romani issue was brought forward to a number of international organizations, such as the EU, the Council of Europe, OSCE and different governments. Roma started to demonstrate a new level of collective consciousness and began to take active part in political and social life. For leading figures in the IRM, the Roma are entering "a new phase of their history", having been given "unprecedented opportunities to become active subjects of politics and policies directed towards them" (14:5). They are "among the last groups in Europe to discover the potential and power of ethnonationalism and to struggle for a political space of their own" (ibid.). The most challenging process for the Romani community has been the building of formal structures of representation and participation in public and political life (14:6). Newly emerging Romani organizations and associations had to gain legitimacy and create national and federal umbrella organizations or associations (ibid). The contemporary structure

was later abandoned. The inter-war period until the end of WW II was a period of decline for the Romani Movement, because of the Nazi persecution and extermination of more than 1.5 million Roma. The rise of the IRM started immediately in the post-war era. 
of the IRM can be presented in a collage form (14:34). It consists of the Romani international organizations, the local/ national parties and associations and the individual Romani activists. Often, they may function independently and be active at different levels: local, national or international (ibid.). Its main task is to become a pressure and interest group, so that the Roma can be included into society as equal citizens by using democratic institutions (ibid.). Legitimate representation is to be achieved by means of democratic elections, both at national and international levels (ibid.). The IRM can further be perceived as an example of global Transnational Social Movements (TSMs) in terms of its organization, target, problems and mobilization (15). It resembles the movements of other indigenous peoples, which have been successful in entering world politics without any conventional sources of power or influence (15). Following Miroslav Hroch's famous categorization of the stages of development of a nationalist movement $(16)^{2}$, we can express a hypothesis that the contemporary development of the IRM is at an intermediary stage between the first phase of work devoted to the standardization of Romani language, history and cultural diacritics and the second, of denouncing an underprivileged position and upgrading a stigmatized pariah status. However, we can hardly speak of the IRM as a truly global mass TSM, as it is rather an elite project with a top-down spread of ideas and activities, mostly existing at the supranational level in the form of different non-profit organizations. In order to reach the third phase of a mass national movement, more work will be necessary at the grassroots level to create strong political identity and infuse a sense of national belonging.

Gheorghe focuses on the social construction of Romani identity and the results of this transformation, when interacting with social institutions (1:157). For him, upgrading previous social identity means using this constructed identity as a "political crutch" to work with political institutions (ibid.). Therefore, improved social identity becomes a tool for ethnic and cultural recognition and for

\footnotetext{
${ }^{2}$ Miroslav Hroch defines several distinct phases of a nationalistic movement (16: 28): 1) increased scholarly attention to the history, language and culture of the nation; 2) a period of patriotic agitation, including the denouncement of an underprivileged situation and the spreading of national consciousness; 3 ) and the construction of a mass national movement with the participation of all classes and groups in the movement.
}

obtaining desired socio-economic resources. Applying Nancy Fraser's (17) interpretative framework, future studies of the IRM will need to trace the extent to which such changes in ethnic representation of the Roma can influence the distribution of certain material demands, which on their part can affect stratification and social justice in the macrosocial political agenda.

The concept of the Roma nation emerged during the First World Roma Congress in London in 1971, when the basic symbols of the nation were coined. For Romani militants, such a nation exists more in symbolic terms, since Roma live dispersed worldwide; therefore, it does not apply to the Romani case in traditional terms (14: 18). It has no territorial demands, since the insistence on territory, as history shows, may lead only to "disasters and massacres" (18: 216). This new nation is placed within the concept of global society and the need for states and international institutions to change in accordance with these new rules, to which Roma would like to contribute (18: 216-217). Traditional narratives of the nation relate a given place with symbolic and actual power that it reifies; therefore, the formation of national identity is perceived as necessarily related to such territory (19). Lacking its own territory, the Roma nation is still to be united by its cultural heritage, history and language. However, important aspects of the Roma nation are the emphasis on multiculturalism, individual, rather than universal human rights, and a victimhood status, resulting from a long history of discrimination, persecution and extermination, perceived as continuing until present days. While multiculturality may present problems in creating a homogenous culture, a common history of discrimination and persecution in the form of a linear historical narrative can have a strong unifying potential. Language, on the other hand, plays the role of a symbolic territory; therefore, its standardization and the creation of a shared literary tradition, myths and symbols are familiar cultural strategies in established forms of nation-building.

Transnationalism, on the other hand, as a common tool for dispersed, discriminated and disadvantaged groups, such as the Roma, relies on support from global human rights organizations, which can exert pressure on national and local levels (20:4). The postnational vision of nationhood is also related to the shrinking role of the state and the emergence of a larger transnational society, which requires redistribution of state powers "downwards" to different civic initiatives, or "upwards", to supranational bodies and 
organizations, such as the UN, NATO or the World Bank (21:375-378). Contemporary Romani nationalism relies particularly on the reconfiguration and redistribution of such powers, promoting a human rights ideology as a central nation-building device, supported by the work of supranational organizations and International Governmental Organizations (IGOs), such as the International Romani Union (IRU), the European Roma Rights Centre (ERRC), the European Roma and Travellers Forum (ERTF) and the Organization for Security and Cooperation in Europe, Office for Democratic Institutions and Human Rights, Contact Point for Roma and Sinti Issues (OSCE /ODIHR/ CPRSI). A new European Roma Institute (ERI) will support and promote Romani culture and identity and create a positive image against widespread anti-Gypsyism. Such supranational Romani organizations collaborate with a network of local level NGOs and human rights organizations with the purpose of promoting particular values, developing Roma-related policies, monitoring their state implementation and function as pressure groups, when confronted with the resistance of governments or local officials.

\section{NEW TRAJECTORIES IN ROMANI NATION BUILDING}

There have been several contemporary developments in the IRM as a continuation of previous identity politics: 1) greater unification, stronger group mobilization and struggles for legitimacy at the supranational level; 2) emphasis on discrimination and human rights as main objectives of the movement and demands for official recognition of the Roma Holocaust (the Porrajmos); 3) developing new values as part of the internal morphogenesis if the IRM vis-àvis working with non Roma; 4) creating new alliances and grassroots initiatives for building Romani political identity and achieving political power. The ERTF, the product of a political compromise between IRU and RNC, has been working towards achieving legitimacy as a Romani representative body with EU institutions since 2004. It has also promoted the idea of the inclusion of Romani Holocaust victims in formal UN commemorative practices. The 70th anniversary of the liberation of AuschwitzBirkenau and the destruction of the Ziganneurcamp drew together large numbers of young Roma at a Europe-wide event, including Bulgarian Roma, united by the ideas of memory preservation and the struggle against hatred and racism in Europe (22). Slawomir Kapralski considers that such commemorative practices and rituals lead to the standardization of the symbolic language in processes of Romani identity building (23: 1011). Undeniably, the Porrajmos carries strong emotional and mobilizing capacity in identity struggles and the potential for distribution of a wide range of resources. The emphasis on a victimized identity is understood as a means for institutional pressure in fighting growing anti-Roma prejudices, discrimination and racism in Europe. As Gheorghe shares, "the Holocaust as an operator allows an immediate switch from local experiences to the disturbing spectre of concentration camps and allows us to portray the plight of Roma communities as part of a greater historical narrative" (24: Section 1, Para.19). A common threat may play a significant unifying role, similarly to the US Afro-American Civil Rights Movement, expecting that "a positive response to such aggression might be the emergence of a strong, well-organized Roma movement at international, national and local level to combat the imminent risk of genocide" (ibid.). Therefore, the main objectives of the IRM are as follows: "the organization, mobilization and eventual re-mobilization of Roma, based on pursuing the struggle against racism and discrimination" (24: Section 1, Para. 9).

Self-reliance is an important value that the IRM needs to develop. Donor support, even by "well-meaning gadjo [non-Roma] partners", may lead to patronizing hierarchical relations, which turn Roma into passive recipients and further reinforce their dependency (25: Section 7, Para. 7). External support also creates more competition between Roma organizations for grants and resources, which leads to greater conflict and separatism within Roma communities (26: Ch.4). A change in traditional mentality is advocated with the purpose of gaining trust in open-market competition and cooperating with gadje institutions (24: Section 1, Para. 4). A "mirror image" to the negative defensive image of Roma in relations with gadjo is the traditional concept of pakiv, which "comprises a complex of values, such as belief, trust, confidence, faith, respect, and obedience to the elderly the fundamental elements of the internal cohesion of the Roma group" (25: Section 2, Para. 32). Pakiv, i.e. "trust" and "transparency", must become key values in political competition for Roma parties, coalitions and movements, which must also be more open to consensus politics and accountable to their constituencies (25: Section 8 , Para. 21). "The way out of the vicious circle of blaming an undifferentiated racist "other" and making claims merely on the grounds of 
eternal Roma victimhood", means for Gheorghe, "to take into account our shared responsibilities" (24: Section 3, Para.1). Despite existing asymmetries of power in such relations, considering joint responsibilities is one step towards trust and confidence-building and the renewal of the social contract among actors (ibid.).

One of the significant problems of the IRM is the lack of political clout (25: Section 7, Para.16). Political mobilization is, therefore, to be achieved equally with the help of ethnic parties (25: Section 8, Para. 4) and in cooperation between Roma organizations and other gadjo allies, based on common causes and platforms, leading to joint policies and actions through coalitions (25: Section 8, Para. 4). Attention is shifted from the supranational level to the grassroots level (25: Section 7, Para. 11), so that it can ensure transparency, participation, trust and empowerment (25: Section 9, Para. 10). Effective pressure from below on governments is necessary to produce the desired effect in budget distribution (25: Section 7, Para.7). The grassroots level, however, can be considered the weakest link in the IRM; therefore, special training is provided by different NGOs, such as the ERRC and OSI, in support of civil society organizations (24: Section 22, Para. 20). Collective integration of the Roma, means for Gheorghe, political construction of the Romani people as part of the imagined symbolic Romani nation and of the actual EU community (27: Section 32, Para. 2). This is a process that should be undertaken at the grassroots level up to the highest supranational level by Roma activists, political and intellectual elites, who should create a vision of this (ibid.).

\section{ROMANI INTELLECTUAL ELITES: ROLES AND STRATEGIC POSITIONS}

Most nationalism scholars agree on the significant role played by intellectual elites in traditional processes of nation building (28:56) in maintaining solidarity, producing national ideology, mythology, symbolism and consciousnes (29:91-92). Similarly, the role required by the new Romani elites can be defined as homogenizing and awarenessraising, putting forward the Romani issue to the European level of politics and choosing the directions and strategies of the embryo Romani ethnonationalism (14:7). This is not an easy task for an imagined community existing transnationally, but still within traditional national boundaries. In post-communist countries, "a thin strata of Romani intellectuals, party-activists and a middle-class, a by-product of the state's coercive educational measures" have been the ones playing a leading role in the movement, who found themselves in conflict over legitimacy with the less educated but powerful traditional Romani elites in the community (14:10). This has presupposed their difficult border existence within Roma communities, further complicated by their exclusion from macrosociety, leading to a sense of estrangement and marginality. A marginal position, however, can be a strategic voluntary choice, which may become a position of advantage and power. The intellectual is such a marginal and exilic figure for Edward Said (30: $\mathrm{x}$ ), but also one, who is "the author of the language that tries to speak the truth to power" (30: xiv). Being an exile means for the intellectual "restlessness, movement constantly being unsettled, and unsettling others" (ibid.). The in-between hybrid spaces of intellectual discursive enunciation do not only encourage selfreflexivity, but also provide a terrain for contestation and negotiation of identities (31:58). For Homi Bhabha, hybridity may be treated as an empowering strategy, as it serves to construct "cultural authority within conditions of political antagonism and inequality" (ibid.). It is debatable whether such hybrid, in-between position is a voluntary choice of empowerment for Roma activists and intellectuals. In current antagonistic relations, there are Roma leaders, who will purposefully choose ethnic enclosure and draw strict ethnic boundaries as a means of exerting subversive power. Others will easily abandon their communities and pursue self-interest "successful Roma", who become a sort of "anti-elite," legitimizing and serving a system of institutionalized racism (32). The third way is that of alliances with non-Roma, based on common interest "to achieve mutually beneficial goals in a way that actually improves the living conditions and life chances of 'Roma' people (and others) and which creates solidarity between 'Roma' and 'nonRoma' on the basis of common interests" (33: Section 30, Para.10). However, in the existing structural conditions of power, "it is not 'Roma,' but the mainstream which determines not only who Roma are, but also who they can be" (ibid.). Challenging the defining narratives or the figures that legitimize the integrity of macrosocial boundaries from within and seeking common interests as the basis for new forms of solidarity, can prove to be more successful positions for Romani elites in the struggle to exercise formative power and change the structural conditions of inequality.

\section{CONCLUSION}

The Roma, similarly to other ethnic groups have discovered the power of contemporary 
ethnonationalism as a tool for gaining better social and political representation, upgrading a stigmatized pariah status and obtaining valuable socio-economic resources. The IRM follows some traditional paths in nation building, such as the need for unifying and homogenizing language, culture and history, to create common rituals, myths and symbols of the nation. Simultaneously, ideas about nonterritoriality, transnationality and multiculturality can be considered as informed by current developments in global society and post-nationalism. The voice of the Roma is to grow not only horizontally, but also vertically, on three distinct levels and through combined grassroots civil society initiatives, national and supranational bodies. Processes of unification and standardization, as part of the Romani nation-building project, have been successful in varying degrees in recent years. Developments in the internal morphogenesis of the movement, along with co-operation at the supranational level have influenced external processes of interaction with IGOs, the state and macrosociety, leading to greater unification and making public consciousness aware of Romani growing political mobilization. Successful development of the national idea and increased political participation cannot be carried out without the indispensible role of Romani elites: activists, entrepreneurs and intellectuals, and the mutual penetration and coordination of ideas at all three levels.

\section{REFERENCES}

1. Gheorghe, N., "The Social Construction of Romani Identity." In: Acton. T., Gypsy Politics and Traveller Identity. Hatfield: University of Hertfordshire Press, pp 153$171,1997$.

2. Council of Europe, "Gypsies in the Locality": Report on the Colloquy Held in Liptovsky, Mikulas, Slovakia, 15-17 October, 1992: Proceedings - Congress of Local \& Regional Authorities of Europe Studies \& Texts No. 38, 1992.

3. Grossberg, L., "Identity and Cultural Studies - Is That All There Is?" In: Hall, St. and du Gay, P.(eds), Questions of Cultural Identity. Sage: London, pp 87 - 107, 1996.

4. Jenkins, R., Rethinking Ethnicity. Arguments and Explorations. Sage: London, 1997.

5. Hutchinson, J. and Smith, A. D. (eds), Nationalism. Oxford University Press: Oxford, 1994.

6. Mayall, D., Gypsy Identities 1500-2000. From Egyptians and Moonmen to the Ethnic Romany. Routledge: London, 2004.
GEORGIEVA-STANKOVA N.

7. Barth, F. (ed), Ethnic Groups and Boundaries: The Social Organization of Cultural Difference. Little Brown and Co.: Boston, 1969.

8. Vermeulen, H. and Govers, H. (eds), The Anthropology of Ethnicity. Beyond "Ethnic Groups and Boundaries." HET Spinhuis: Amsterdam, 1994.

9. Glazer, N \& Moynihan, D.P., Ethnicity. Theory and Experience. Harvard University Press: Cambridge, 1975.

10.Roosens, E., Creating Ethnicity. The Process of Ethnogenesis. Sage: London, 1989.

11.Bell, D., "Ethnicity and Social Change." In: Glazer, N. and Moynihan, D. P., Ethnicity. Theory and Experience. Harvard University Press: Cambridge, Massachusetts, pp 141-176, 1975.

12.Benhabib, S., "Civil Society and Politics of Identity and Difference in a Global Context." In: N.J. Smelser \& J.C. Alexander (eds), Diversity and Its Discontents - Cultural Conflict and Common Ground in Contemporary American Society. Princeton University Press: Princeton, pp 293-312, 1999.

13. Matras, Y., "The Development of the Romani Civil Rights Movement in Germany 1945-1996." In: Tebbutt, S. (ed), Gypsies in German-Speaking Society and Literature. Berghahn Books: Oxford, 1998.

14.Mirga, A. and Gheorghe, N., "Roma in the 21st Century. A Policy Paper." PER, 1997.

15.Klimova, I., The Romani Voice in World Politics. The United Nations and Non-State Actors. Ashgate: England, 2005.

16.Guibernau, M., Nations without States. Polity Press: Cambridge, 1999.

17.Fraser, N. and Honneth, A., Redistribution or Recognition. A Political Philosophical Exchange. Verso: London, 2003.

18.Acton, T. and Klimova, I., "The International Romani Union: An East European Answer to West European Questions? Shifts in the Focus of World Romani Congresses 1971-2000.” In: Guy, W. (ed), Between Past and Future: the Roma of Central and Eastern Europe. University of Hertfordshire Press: Hatfield, 2001.

19.Feys, C., "Towards a New Paradigm of the Nation: The Case of the Roma". Journal of Public and International Affairs. Princeton University, 1997. (http://www.wws.princeton.edu/ jpia/1997/ chap1.html)

20.Kennedy, P. and Roudometof, V., "Transnationalism in a Global Age". In: Communities across Borders. Kennedy, P. 
and Roudometof, V. (eds), Routledge: London \& New York, pp 1-26, 2002.

21.Pakulski, J., "Postmodernization, Fragmentation, Globalization". In: Nash, K. \&Alan Scott (eds), The Blackwell Companion to Political Sociology. Blackwell: Oxford, pp 375-385, 2001.

22."Amalipe", "See and Don't Forget: Commemoration of the Romani Holocaust". Centre for Interethnic Dialogue and Tolerance"Amalipe", 2014. (http://amalipe.com/index.php?nav=news\&i $\mathrm{d}=2023$ \&lang $=1$ )

23.Kapralski, S., "Ritual of Memory in Constructing the Modern Identity of Eastern European Romanies." In: Saul, N. and S. Tebbutt (eds), The Role of the Romanies. Images and Counter-Images of "Gypsies". Liverpool University Press: Liverpool, pp 208-225, 2004.

24.Gheorghe, N. and Pulay, G., "Choices To Be Made and Prices To Be Paid: Potential Roles and Consequences in Roma Activism and Policy Making". In: Biro. A., Gheorghe, N. and Kovats, M. et. al Guy, W. (ed.), From Victimhood To Citizenship. The Path of Roma Integration. A Debate. [Kindle Edition]. Pakiv, European Roma Fund, Kossuth Publishing Corporation: Hungary, 2013.

25.Biro, A., "The Price of Roma Integration". In: Biro. A., Gheorghe, N. and Kovats, M. et. al. Guy, W. (ed). From Victimhood To Citizenship. The Path of Roma Integration. $A$ Debate. [Kindle Edition]. Pakiv, European Roma Fund, Kossuth Publishing Corporation: Hungary. 2013.
26.Nirenberg, J. Gypsy Movements. [Kindle edition]. Schlimmer Publishing, 2014.

27.Biro, A. "Workshop debates". In: Biro. A., Gheorghe, N. and Kovats, M. et. al. Guy, W. (ed). From Victimhood To Citizenship. The Path of Roma Integration. A Debate. [Kindle Edition]. Pakiv, European Roma Fund, Kossuth Publishing Corporation: Hungary. 2013.

28.Smith, A.D., Nationalism and Modernism. Routledge: London. 1998.

29. Smith, A.D., National Identity. Penguin: London. 1991.

30. Said. E., Representations of the Intellectual. The 1993 Reith Lectures. Vintage: London. 1994.

31.Bhabha, H., "Culture's in-Between". In: Hall, St. and du Gay, P. (eds). Questions of Cultural Identity. Sage: London, pp. 5360, 1996.

32.Tahir, O., "Next 10 Years. What should We Expect after the "Integration"? Part One." FREEROMA. July 2, 2015. (http://freeroma.wix.com/freeroma\#!Следв ащите-10-години-Какво-ни-очаква-следИнтеграцията-Част-

Пьрва/cmbz/55953e790cf2585ebcdc0a67)

33.Kovats, M., "Integration and the Politicisation of Roma Identity". In: Biro. A., Gheorghe, N. and Kovats, M. et. al. Guy, W. (ed). From Victimhood To Citizenship. The Path of Roma Integration. A Debate. [Kindle Edition]. Pakiv, European Roma Fund, Kossuth Publishing Corporation: Hungary. 2013. 